\title{
Sapindaceae em remanescentes de florestas montanas no sul da Bahia, Brasil ${ }^{1}$
}

\author{
Sapindaceae in remnant montane forests in southern Bahia, Brasil
}

Ricardo de Oliveira Perdiz ${ }^{2,4,6,7}$, María Silvia Ferrucci ${ }^{5}$ \& André Márcio Araujo Amorim ${ }^{2,3,4}$

\begin{abstract}
Resumo
Este trabalho apresenta o tratamento taxonômico de Sapindaceae em três remanescentes de florestas montanas no sul da Bahia, Brasil. Foram registrados seis gêneros e 21 espécies. Paullinia (7 spp.) foi o gênero mais diverso em número de espécies, seguido de Cupania (5 spp.), Allophylus (4 spp.), Matayba e Serjania (2 spp. cada) e Talisia (1 espécie). Foram verificados quatro novos registros de ocorrência (Allophylus leucoclados, A. petiolulatus, Cupania furfuracea e Matayba intermedia) para a Região Nordeste. Nove espécies foram ilustradas pela primeira vez: Allophylus leucoclados, Cupania racemosa, C. rugosa, Cupania sp. 1, Paullinia ferruginea, P. micrantha, P. racemosa, P. revoluta e Serjania salzmanniana. O trabalho inclui uma chave de identificação, descrições, ilustrações, informações sobre floração e frutificação, além de comentários taxonômicos e de distribuição geográfica de cada espécie encontrada.
\end{abstract}

Palavras-chave: Floresta Atlântica, floresta ombrófila, florística, Paullinia, Sapindales.

\begin{abstract}
This work presents the taxonomic study of Sapindaceae from three areas of montane forest remnants in southern Bahia, Brazil. Six genera and 21 species were registered. Paullinia (7 spp.) was the most diverse genus in number of species, followed by Cupania (5 spp.), Allophylus (4 spp.), Matayba and Serjania (2 spp. each) and Talisia (1 sp.). Four new occurrence records were registered (Allophylus leucoclados, A. petiolulatus, Cupania furfuracea and Matayba intermedia) for Northeast Brazil. Nine species were illustrated for the first time: Allophylus leucoclados, C. racemosa, C. rugosa, Cupania sp. 1, Paullinia ferruginea, P. micrantha, $P$. racemosa, $P$. revoluta and Serjania salzmanniana. This work includes an identification key, descriptions, illustrations, notes on phenology and comments on the taxonomy and geographic distribution of each species. Key words: Atlantic Forest, ombrophilous forest , floristics, Paullinia, Sapindales.
\end{abstract}

\section{Introdução}

Sapindaceae Juss. possui ca. 141 gêneros e 1.900 espécies e distribuição cosmopolita, com a maioria das espécies nas zonas tropicais e subtropicais (Buerki et al. 2010). No Brasil ocorrem 27 gêneros e aproximadamente 419 espécies, com estimativa de 136 espécies para a Região Nordeste (Somner et al. 2014). A família ocupa variados hábitats, com boa representação em todos os domínios vegetacionais brasileiros, possuindo maior diversidade nos domínios Amazônico e Atlântico (Acevedo-Rodríguez 1993) com 220 e 191 espécies, respectivamente (Somner et al. 2014).

Sapindaceae abriga arbustos, árvores e trepadeiras, herbáceas ou lenhosas, com folhas compostas alternas, pari- ou imparipinadas; as

\footnotetext{
Parte da dissertação de Mestrado do primeiro autor.

${ }^{2}$ Universidade Estadual de Feira de Santana, Depto. Ciências Biológicas, Programa de Pós-graduação em Botânica, Av. Transnordestina s/n., 44.036-900, Feira de Santana, BA, Brasil.

${ }^{3}$ Universidade Estadual de Santa Cruz, Depto. Ciências Biológicas, Km 16 rod. Ilhéus-Itabuna, 45.600-970, Ilhéus, BA, Brasil.

${ }^{4}$ Herbário Centro de Pesquisas do Cacau, CEPEC, Km 22 rod. Ilhéus Itabuna, 45.650-000, Ilhéus, BA, Brasil.

${ }^{5}$ Instituto de Botánica del Nordeste (UNNE-CONICET), Sargento Cabral 2131, C.C. 209, 3400, Corrientes, Corrientes, Argentina.

${ }^{6}$ Centro de Estudos Integrados da Biodiversidade Amazônica (CENBAM), Núcleo Regional de Roraima, Boa Vista, RR, Brasil.

${ }^{7}$ Autor para correspondência: ricoperdiz@gmail.com
} 
flores são pequenas (geralmente menores que $5 \mathrm{~mm}$ compr.) e podem ser actinomorfas ou zigomorfas; os frutos são variados, podendo ser esquizocarpos com mericarpos samarídeos ou cocos drupáceos, cápsulas loculicidas ou septífragas, ou bacáceos. Os táxons arbustivo-arbóreos geralmente possuem folíolo terminal abortivo enquanto as trepadeiras geralmente apresentam látex alvo e estípulas.

Estudos florísticos recentes continuam revelando novidades taxonômicas em Sapindaceae no território brasileiro, incluindo dois gêneros novos (Acevedo-Rodríguez 2011, 2012) além de diversas espécies descritas nos últimos cinco anos (e.g., Acevedo-Rodríguez 2012; Perdiz et al. 2012; Ferrucci \& Coulleri 2013). Contudo, existem poucos tratamentos taxonômicos de Sapindaceae disponíveis no leste do Brasil (Reitz 1980; Somner 1997; Ferrucci 2006; Somner et al. 2009a,b). No estado da Bahia, apenas áreas de campo rupestre (Ferrucci 1995; Ferrucci \& Somner 2005) foram alvo de estudo taxonômico.

Levantamentos recentes no sul da Bahia (e.g., Amorim et al. 2009; Rocha \& Amorim 2012; Coelho \& Amorim 2014; Leitman et al. 2014) investigaram aspectos florísticos e ecológicos de florestas montanas em diferentes áreas, revelando uma flora muito diversa, com elevado número de espécies novas e conexões fitogeográficas anteriormente desconhecidas com a flora da Região Sudeste (detalhes em Amorim et al. 2009). Esses estudos concentraram-se em três fragmentos de floresta em regiões montanhosas e que possuem a vegetação relativamente preservada, principalmente nos pontos de altitude mais elevada.

Visando preencher uma lacuna no conhecimento taxonômico de Sapindaceae para as florestas ombrófilas montanas do sul da Bahia, e de forma a contribuir com o projeto Flora da Bahia (Giulietti et al. 2006), este trabalho teve como objetivo apresentar um tratamento taxonômico da família considerando três remanescentes de floresta montana na região, incluindo uma chave de identificação, descrições, ilustrações, comentários taxonômicos e de distribuição geográfica.

\section{Material e Métodos}

O estudo foi realizado em três fragmentos de floresta montana na região sul da Bahia: PARNA de Serra das Lontras, nos municípios de Arataca, São José da Vitória e Una; Reserva Particular Serra da Pedra Lascada, em Barro Preto; e RPPN Serra Bonita, em Camacan (Fig. 1). Descrições mais detalhadas sobre as áreas de estudo, incluindo dados climáticos e de relevo foram apresentados em Amorim et al. (2009), Rocha \& Amorim (2012), Liuth et al. (2013), Coelho \& Amorim (2014) e Leitman et al. (2014).

Foram realizadas expedições de coleta no período de fevereiro de 2009 a setembro de 2011. Também foram utilizadas as amostras da coleção "Florestas Montanas do sul da Bahia", realizadas no período 2004-2008. Estes materiais foram depositados no herbário CEPEC, com duplicatas distribuídas para os herbários CTES, HUEFS, NY, RB e US. As coleções dos herbários ALCB, CEPEC, CTES, HEPH, HRB, HUEFS, INPA, M, MBML, MO, NY, RB e UB foram analisadas através de empréstimos, visitas ou consultas pela internet. Tipos nomenclaturais e fotografias dos tipos também foram analisados.

O tratamento taxonômico incluiu dados referentes a todo o material coletado nas áreas de estudo e materiais complementares. Apenas um material representativo de cada área de estudo

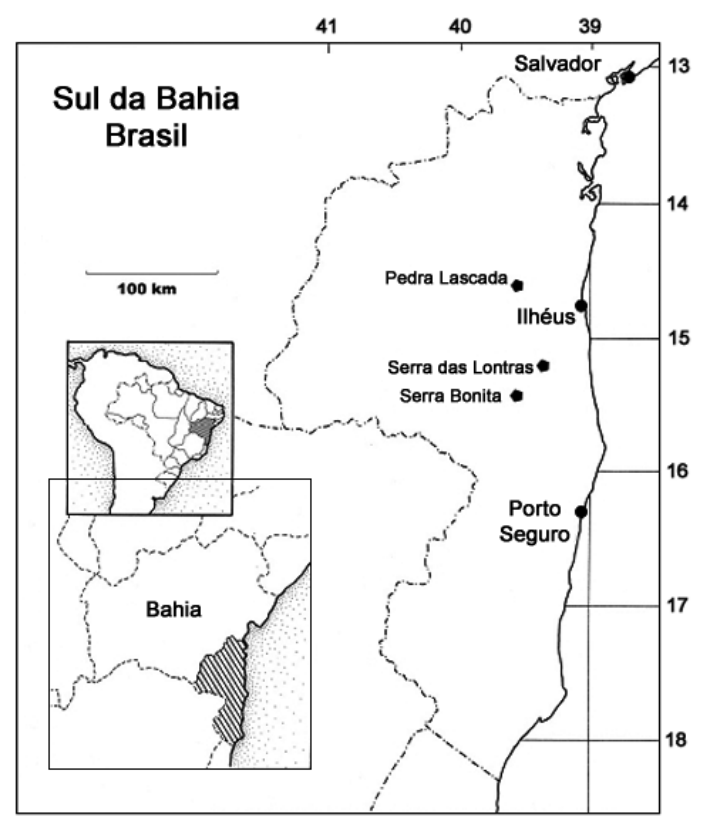

Figura 1 - Mapa mostrando as três áreas estudadas de floresta montana no sul da Bahia, Brasil: PARNA Serra das Lontras (Serra das Lontras), Serra da Pedra Lascada (Pedra Lascada) e RPPN Serra Bonita (Serra Bonita). Modificado de Amorim et al. (2009).

Figure 1 - Map showing locations of the three studied areas of montane forest in southern Bahia, Brazil: PARNA Serra das Lontras, Serra da Pedra Lascada, and RPPN Serra Bonita. Modified from Amorim et al. (2009). 
foi citado no material examinado. Os táxons foram arranjados em ordem alfabética. Os dados de floração e frutificação foram baseados apenas nas exsicatas das áreas de estudo. As descrições não são simétricas entre espécies de gêneros diferentes, havendo uniformização dentro de um mesmo gênero e entre gêneros diferentes apenas quando determinadas características foram utilizadas na chave de identificação.

A terminologia utilizada para descrição dos caracteres morfológicos foi baseada em Font Quer (1965) e Rizzini (1977) para as partes vegetativas, Silva et al. (2013) para os frutos (para Talisia, Acevedo-Rodríguez 2003) e Tamaio \& Angyalossy (2009) para a variação cambial em Paullinia e Serjania. As domácias foram descritas como barbadas (em forma de tufos de tricomas), foveoladas ou urceoladas. Os cincinos foram descritos como pauci- (até quatro flores) ou plurifloros (mais de quatro flores). Utilizaram-se no tratamento taxonômico as seguintes abreviaturas: alt. (altura), ca. (cerca de), compr. (comprimento), larg. (largura), diâm. (diâmetro) e vs. (versus). A distribuição geográfica das espécies no Brasil foi baseada em bibliografia especializada e análise das coleções dos herbários supracitados. Seguimos o conceito de Coutinho (2006) ao considerarmos os domínios fitogeográficos brasileiros.

\section{Resultados e Discussão}

As áreas estudadas apresentaram um total de seis gêneros e 21 espécies de Sapindaceae. Foram verificados quatro novos registros de ocorrência (Allophylus leucoclados, A. petiolulatus, Cupania furfuracea e Matayba intermedia) para a Região Nordeste. Em relação à lista apresentada por Amorim et al. (2009), houve um acréscimo de três espécies, a determinação de seis espécies naquele momento ainda não identificadas e a atualização nomenclatural de cinco táxons. Nove espécies foram ilustradas pela primeira vez: Allophylus leucoclados, Cupania racemosa, $C$. rugosa, Cupania sp. 1, Paullinia ferruginea, $P$. micrantha, $P$. racemosa, $P$. revoluta e Serjania salzmanniana.

É interessante notar que ca. 62\% (13 espécies) das Sapindaceae ocorrentes nas áreas de estudo são endêmicas no domínio Atlântico, o que corrobora os dados de Stehmann et al. (2009) sobre o elevado nível de endemismo de plantas vasculares encontradas nesta formação e reafirma o conhecido caráter de hotspot de biodiversidade atribuído às florestas da região sul da Bahia (Thomas et al. 1998; Martini et al. 2007).

\section{Chave de identificação para as espécies de Sapindaceae em florestas montanas no sul da Bahia, Brasil}

1. Árvores ou arbustos, sem gavinhas; estípulas e látex ausentes.

2. Folhas 1-3-folioladas, sem folíolo terminal abortivo; flores zigomorfas; fruto esquizocárpico, mericarpos drupáceos; sementes sem arilo ou sarcotesta.

3. Folhas 1-folioladas

1.1 Allophylus leucoclados

3'. Folhas 3-folioladas.

4. Ramos vegetativos hirsuto-pubescentes; margem do folíolo conspicuamente serrulada até a base; veias terciárias percurrentes 1.4 Allophylus sericeus

4'. Ramos vegetativos glabros ou pubérulos; margem dos folíolos serruladas ou serradas apenas no terço distal; veias terciárias reticuladas.

5. Folíolo terminal 12,3-15,8 cm compr., peciólulo do folíolo terminal 4-20 mm compr.; tirso birramificado na base 1.2 Allophylus petiolulatus

5'. Folíolo terminal 5-10,7 cm compr., peciólulo do folíolo terminal 1-2 mm compr.; tirso sem ramificação na base 1.3 Allophylus semidentatus

2'. Folhas com mais de três folíolos, folíolo terminal abortivo; flores actinomorfas; fruto bacáceo ou cápsula loculicida; sementes com arilo ou sarcotesta.

6. Peciólulos pulvinulados e dilatados; folhas sem domácias; pétalas com apêndice basal simples; fruto bacáceo, unilocular; sementes com sarcotesta 6.1 Talisia macrophylla

6'. Peciólulos sem pulvínulo; folhas geralmente com domácias; pétalas com apêndice basal bipartido; fruto cápsula loculicida, com duas a três valvas; sementes com arilo.

7. Cálice dialissépalo com abertura não precoce.

8. Folíolos com hipofilo glabro a pubérulo, margem inteira, domácias conspícuas. 
9. Apêndice petalífero maior que a pétala; cápsula 2-lobada, obtriangular, fortemente compressa lateralmente, lobos agudos 2.2 Cupania ludowigii

9'. Apêndice petalífero menor que a pétala ou rudimentar (flores desconhecidas em Cupania sp. 1); cápsula 3-lobada, trígono-obovoide, lobos agudos, obtusos ou arredondados.

10. Folhas 8-10-folioladas; cápsula com lobos agudos, endocarpo tomentoso

.2.3 Cupania racemosa

10'. Folhas 4-5-folioladas; cápsula com lobos obtusos ou arredondados, endocarpo viloso 2.5 Cupania sp. 1

8'. Folíolos com hipofilo furfuráceo-tomentoso ou viloso, ferrugíneo, margem subrepanda a levemente serrulada ou inciso-denteada, domácias inconspícuas, cobertas pelo indumento.

11. Folhas 10-25-folioladas, margem crenado-serrada; hipofilo furfuráceo-tomentoso; cápsula com lobos obtusos 2.1 Cupania furfuracea

11'. Folhas 6-9-folioladas, margem subrepanda a levemente serrulada, dentes geralmente inconspícuos; hipofilo viloso; cápsula com lobos agudos. 2.4 Cupania rugosa

7'. Cálice gamossépalo com abertura precoce.

12. Folhas 8-24-folioladas, folíolos geralmente conduplicados e recurvados, veias secundárias arqueado-ascendentes no terço proximal, domácias geralmente presentes, urceoladas

12'. Folhas 4-10-folioladas, folíolos não conduplicados e recurvados, veias secundárias obliquas e retilíneas no terço proximal, levemente arqueadas no terço distal, domácias ausentes ......

1'. Trepadeiras semilenhosas ou lianas, com gavinhas; estípulas e látex presentes.

13. Fruto cápsula septífraga; sementes com arilo.

14. Folhas 1-folioladas

4.1 Paullinia unifoliolata

14'. Folhas com mais de um folíolo.

15. Cápsula alada, trígono-obovoide.

16. Margem dentado-serrada; venação craspedódroma mista; cápsula com alas pouco desenvolvidas 4.4 Paullinia micrantha

16'. Margem inteira, denticulada, crenado-serrada ou serrada; venação broquidódroma; cápsula com alas bem desenvolvidas.

17. Ramos vegetativos e reprodutivos glabros; domácias barbadas, conspícuas; cápsula com epicarpo glabro e alas inflexas 4.5 Paullinia racemosa

17'. Ramos vegetativos e reprodutivos velutinos; domácias ausentes; cápsula com epicarpo velutino e alas planas 4.6 Paullinia revoluta

15'. Cápsula não alada, globosa, elipsoide ou obovoide.

18. Folhas 7-9-folioladas, 3-4-jugas, folíolos basais ternados, venação broquidódroma; epicarpo e endocarpo glabros 4.2 Paullinia carpopoda

18'. Folhas 5-folioladas, 2-jugas, folíolos basais não ternados, venação craspedódroma, mista ou não; epicarpo e endocarpo pilosos.

19. Estípulas subuladas, caducas; folíolo com margem denticulada a crenadoserrada, dentes obtusos, venação craspedódroma mista; cápsula elipsoide ou globosa, 1,5-2,6 × 1,2-1,9 cm, estípite 2-6 mm compr., uma semente por cápsula 4.3 Paullinia ferruginea

19'. Estípulas ovadas, escariosas e persistentes; folíolo com margem serrada, venação craspedódroma; cápsula elipsoide ou obovoide, 1,7-2 × 0,5-0,9 cm, estípite ca. $1 \mathrm{~mm}$ compr., geralmente três sementes por cápsula

4.7 Paullinia rubiginosa

13'. Fruto esquizocarpo com três mericarpos samarídeos; sementes sem arilo.

20. Trepadeira semilenhosa, cilindro vascular composto, com três cilindros vasculares periféricos, equidistantes, ao redor de uma medula oca; folíolos de margem dentada; sépalas 4; mericarpos $1,8-2,5 \times 0,5-1 \mathrm{~cm}$ 5.1 Serjania communis

20'. Liana, cilindro vascular simples, 5-lobado, lobos arredondados; folíolos de margem inteira ou com dentes inconspícuos; sépalas 5; mericarpos 3,8-4,4 × 1,3-1,5 cm 
1.1 Allophylus leucoclados Radlk. in Mart., Eichl. \& Urban, Fl. bras. 13(3): 473. $1900 . \quad$ Fig. 2a-e Árvore ou arbusto, até $6 \mathrm{~m}$ alt., ramos vegetativos glabros ou pubérulos, alvacentos a acizentados, estípula e látex ausentes. Folhas 1-folioladas, pecíolo 3,7-5,5 cm compr., peciólulo 4-5 mm compr., folíolos elípticos, lanceolados ou oblongo-lanceolados, 13-20,5 × 4,5-9,6 cm, base cuneada, raro obliqua, ápice acuminado, margem inteira ou serrulada; venação craspedódroma, veias terciárias reticuladas; epifilo glabro, hipofilo glabro ou pubérulo; domácias ausentes. Tirso espiciforme, não ramificado na base, eixos pubérulos, cincinos paucifloros, pedicelo floral 0,6-1 mm compr., brácteas ca. $0,8 \mathrm{~mm}$ compr., ovadas. Flores 3-4 mm compr.; sépalas 4(-5), face externa pubérula e interna glabra; pétalas obovadas ou espatuladas, apêndice petalífero formado por duas linguetas inflexas. Cocos 1-2, obovoides, $1,1-1,5 \times 0,7-1 \mathrm{~cm}$, epicarpo glabriúsculo; semente, ca. $1 \times 0,8 \mathrm{~cm}$.

Material selecionado: Arataca, PARNA Serra das Lontras, 12.X.2008, fl., A. Jardim et al. 112 (CEPEC, CTES, HUEFS). Camacan, RPPN Serra Bonita, 17.VII.2009, est., A.M. Amorim et al. 7875 (CEPEC).

Endêmica no domínio Atlântico (Somner \& Ferrucci 2009), Allophylus leucoclados, conhecida anteriormente apenas no Espírito Santo e Rio de Janeiro, é registrada pela primeira vez na Região Nordeste. As folhas 1-folioladas a distinguem facilmente das outras espécies de Allophylus ocorrentes na área de estudo, que são geralmente 3-folioladas. Coletada com flores de setembro a outubro e frutos de fevereiro a maio, julho e dezembro.

1.2 Allophylus petiolulatus Radlk., Ergänz. Monogr. Serjania 16(1): 181. 1886. Iconografia: Ferrucci et al. (2009), prancha 1, fig. c-d.

Árvore ou arbusto, até $25 \mathrm{~m}$ alt., ramos vegetativos glabros ou pubérulos, castanhoacizentados ou castanhos, estípula e látex ausentes. Folhas 3-folioladas, pecíolo 4,2-10,5 cm compr., peciólulo lateral até ca. $6 \mathrm{~mm}$ compr., terminal 4-20 mm compr., folíolos elípticos, 12,3-15,8 × 3,6-4,5 $\mathrm{cm}$, base cuneada no folíolo terminal, obliqua nos folíolos laterais, ápice agudo a acuminado, margem serrulada a partir do terço distal; venação craspedódroma mista, veias terciárias reticuladas; epifilo glabro, hipofilo pubérulo; domácias barbadas. Tirso racemiforme, birramificado na base, eixos pubérulos a tomentosos, cincinos paucifloros, pedicelo floral 1-1,2 cm compr., brácteas ca. $1 \mathrm{~mm}$ compr., ovadas ou lanceoladas. Flores ca. 3,5 mm compr.; sépalas 4, ambas as faces glabriúsculas; pétalas espatuladas, apêndice emarginado, formando duas linguetas inflexas. Cocos 1-2, subglobosos, obovoides, 0,9-1,4 × 0,7-1 cm, epicarpo glabriúsculo; semente não vista. Material selecionado: Arataca, PARNA Serra das Lontras, 13.IX.2009, est., R. Perdiz et al. 726 (CEPEC, HUEFS). Camacan, RPPN Serra Bonita, 18.V.2010, fl., D. Rocha 1136 (CEPEC).

Disjunta entre os domínios Atlântico e Amazônico (Somner et al. 2014), presente na Bolívia e Brasil (Somner et al. 2009b), Allophylus petiolulatus é morfologicamente semelhante a $A$. semidentatus, diferindo desta por apresentar o peciólulo terminal de maior comprimento, 4-20 mm compr. (vs. 1-2 mm compr.), folíolos maiores, $12,3-15,8 \times 3,6-4,5 \mathrm{~cm}$ (vs. $5-10,7 \times 1,6-4 \mathrm{~cm}) \mathrm{e}$ tirso birramificado na base (vs. não ramificado na base). Coletada com flores em maio.

1.3 Allophylus semidentatus (Miq.) Radlk. in Engl. \& Prantl, Nat. Pflanzenfam. 3(5): 312. 1895. Iconografia: Ferrucci et al. (2009), prancha 1, fig. e-g.

Árvore, até $6 \mathrm{~m}$ alt., ramos vegetativos glabros ou pubérulos, castanho-acizentados ou castanhos, estípula e látex ausentes. Folhas 3-folioladas, pecíolo 2,5-4,7 cm compr., peciólulos lateral e terminal 1-2 $\mathrm{mm}$ compr., folíolos obovados, oblanceolados ou elípticos, 5-10,7 × $1,6-4 \mathrm{~cm}$, base cuneada no folíolo terminal, obliqua nos laterais, ápice acuminado, margem serrada a partir da metade distal; venação craspedódroma mista, veias terciárias reticuladas; epifilo glabro, hipofilo glabro ou pubérulo; domácias barbadas, às vezes ausentes. Tirso racemiforme, não ramificado na base, eixos pubérulos, cincinos paucifloros, pedicelo floral 2-2,3 $\mathrm{mm}$ compr., brácteas $0,5-1$ $\mathrm{mm}$ compr., ovado-subuladas. Flores $1,5-3 \mathrm{~mm}$ compr.; sépalas 4 , ambas as faces glabras, pétalas espatuladas ou obovadas, apêndice emarginado, formando duas linguetas inflexas. Cocos 1-2, obovoides, $0,6-0,8 \times 0,5-0,6 \mathrm{~cm}$, epicarpo glabro; semente 3,5-4,6 × 3,5-4 mm.

Material selecionado: Arataca, PARNA Serra das Lontras, 6.V.2011, est., R. Perdiz et al. 750 (CEPEC). Camacan, R PPN Serra Bonita, 29.X.2004, fr., A.M. Amorim et al. 4383 (CEPEC).

Allophylus semidentatus possui ampla distribuição, disjunta entre os domínios Atlântico e Amazônico (Somner et al. 2014). Ver comentários em A. petiolulatus. Coletada com frutos em outubro. 


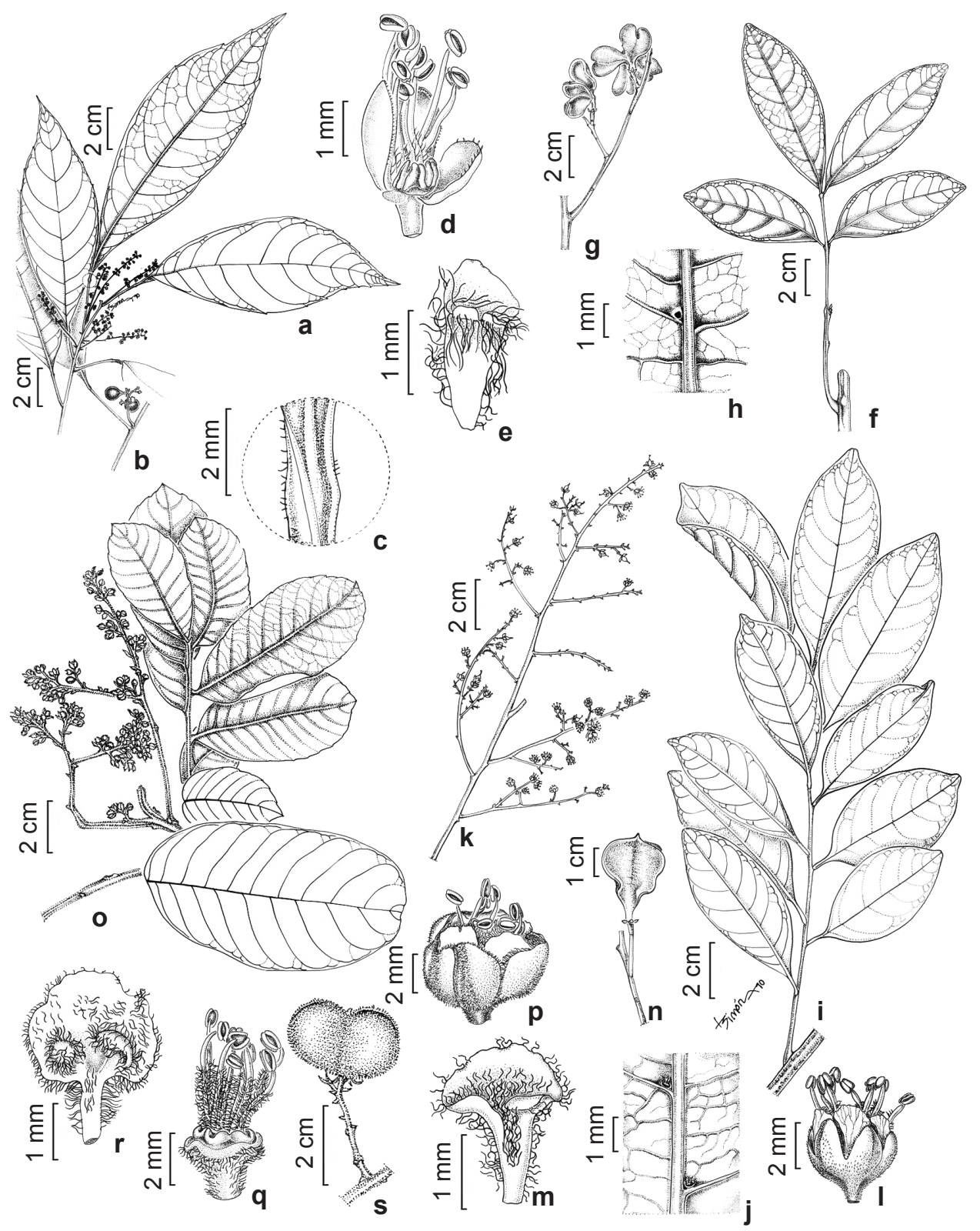

Figura 2 - a-e. Allophylus leucoclados - a. ramo com flores; b. ramo com frutos; c. detalhe da articulação do pecíolo; d. flor estaminada com parte do perianto removido, evidenciando os lobos nectaríferos e estames; e. face adaxial da pétala, evidenciando apêndice petalífero; f-h. Cupania sp. 1 - f. ramo vegetativo; g. ramo com frutos; h. detalhe do hipofilo, evidenciando uma domácia foveolada; i-n. Cupania racemosa - i. ramo vegetativo; j. detalhe do hipofilo, evidenciando domácias foveoladas; $\mathrm{k}$. inflorescência; 1. flor estaminada; m. face adaxial da pétala, evidenciando apêndice petalífero; n. ramo com cápsula imatura; o-s. Cupania rugosa - o. ramo com flores; p. flor estaminada; q. flor estaminada com perianto removido evidenciando disco nectarífero e estames; $r$. face adaxial da pétala evidenciando apêndice petalífero; s. ramo com cápsula imatura. (a, c-e Amorim 524; b Amorim 4973; f-g Fiaschi 2647; i-m Perdiz 432; n Perdiz 557; o, s Carvalho 5031; p-r Folli 15).

Figure 2 -a-e. Allophylus leucoclados - a. branch with flowers; b. branch with fruits; c. detail of petiole articulation; d. staminate flower with perianth removed showing nectary lobes and stamens; e. adaxial view of petal showing petal appendage; f-h. Cupania sp.1 - f. sterile branch; g. branch with fruits; h. detail of leaflet abaxial surface showing pit domatia; i-n. Cupania racemosa - i. sterile branch; j. detail of leaflet abaxial surface showing pit domatia; k. inflorescence; 1. staminate flower; $\mathrm{m}$. adaxial view of petal showing petal appendage; n. immature capsule; o-s. Cupania rugosa - o. branch with flowers; p. staminate flower; q. staminate flower with perianth removed showing nectary disk and stamens; r. adaxial view of petal showing petal appendage; s. immature capsule. (a, c-e Amorim 524; b Amorim 4973; f-g Fiaschi 2647; i-m Perdiz 432; n Perdiz 557; o, s Carvalho 5031; p-r Folli 15). 
1.4 Allophylus sericeus (Cambess.) Radlk., Sitzungsber. Math.-Phys. Cl. Königl. Bayer. Akad. Wiss. München 20: 230. 1890. Iconografia: Silva et al. (2013), fig. 1a-b.

Árvore, até $8 \mathrm{~m}$ alt., ramos vegetativos hirsutopubescentes, alvacentos a amarelados, estípula e látex ausentes. Folhas 3-folioladas, pecíolo 4,5-9 cm compr., peciólulos lateral e terminal 2-6 mm compr., folíolos elípticos, ovados ou obovados, laterais às vezes falcados, 10-20,5 × 4,3-9,4 cm, base atenuada ou cuneada nos folíolos terminais, obliqua nos laterais, ápice acuminado, mucronado, margem serrulada; venação craspedódroma, veias terciárias percurrentes; epifilo pubescente nas veias primárias e secundárias, hipofilo velutino; domácias barbadas. Tirso espiciforme, não ramificado na base, eixos pilosos, cincinos plurifloros, pedicelo floral 1-1,2 mm compr., brácteas ca. 0,8 mm compr., ovado-lanceoladas. Flores 1,8-2 mm compr.; sépalas 4, ambas as faces pilosas; pétalas espatuladas, apêndices de ápice emarginado, formando duas linguetas inflexas. Cocos 1-2, obovoides, 1-1,3 × 0,9-1,2 cm, epicarpo hirsutopubescente; semente ca. $11 \times 8 \mathrm{~mm}$.

Material selecionado: Barro Preto, Serra da Pedra Lascada, 23.I.2004, fr., P. Fiaschi et al. 1913 (CEPEC).

Com ocorrência no domínio Atlântico e do Cerrado (Somner et al. 2014), Allophylus sericeus difere das espécies de Allophylus da área basicamente por apresentar indumento hirsuto-pubescente nos ramos vegetativos e folhas 3-folioladas. Coletada com frutos de novembro a janeiro e em março.

2.1 Cupania furfuracea Radlk., Sitzungsber. Math.-Phys. C1. Königl. Bayer. Akad. Wiss. München 9: 567. 1879.

Árvore, até $25 \mathrm{~m}$ alt., ramos vegetativos furfuráceo-tomentosos, tricomas ferrugíneos, estípula e látex ausentes. Folhas 10-25-folioladas, pecíolo 3,5-10 $\mathrm{cm}$ compr., peciólulo não pulvinulado, 4-5 mm compr., folíolos coriáceos, oblongos, oblongo-lanceolados, 9,4-22 × 3,5-4,6 $\mathrm{cm}$, base cuneada ou obliqua, ápice agudo, margem crenado-serrada, dentes obtusos, revoluta; venação craspedódroma, veias terciárias reticuladas; epifilo glabro, hipofilo furfuráceo-tomentoso; domácias foveoladas, inconspícuas. Tirso paniculiforme, eixos furfuráceo-tomentosos, cincinos paucifloros, pedicelo floral 1,5-2 mm compr., brácteas 2,5-4 mm compr., ovadas. Flores ca. $5 \mathrm{~mm}$ compr.; sépalas com face abaxial lanoso-tomentosa; pétalas obovadas, apêndice petalífero basal bipartido, rudimentar, marginal. Cápsula 1,4-1,7 × 1,4-1,8 $\mathrm{cm}$, trígono-obovoide, ápice emarginado, 3-lobada, lobos obtusos, estípite 2-3 mm compr., epicarpo ferrugíneo-tomentoso, rugulado, endocarpo viloso; sementes obovoides, 10-12 × 7-9 mm, arilo cobrindo os $2 / 3$ basais da semente.

Material selecionado: Camacan, RPPN Serra Bonita, 7.V.2010, fl., R. Perdiz et al. 675 (CEPEC, CTES, HUEFS).

Endêmica no domínio Atlântico (Somner \& Ferrucci 2009), Cupania furfuracea é morfologicamente distinta das demais espécies amostradas de Cupania, especialmente por apresentar indumento furfuráceo-tomentoso nos ramos vegetativos e partes reprodutivas e folíolos de margem crenado-serrada com dentes obtusos. Segundo Valente et al. (2013), possui status vulnerável (VU). É o primeiro registro da espécie para a Região Nordeste do Brasil.

2.2 Cupania ludowigii Somner \& Ferrucci, Bot. J. Linn. Soc. 146(2): 217-221. 2004. Iconografia: Somner \& Ferrucci (2004), fig. 1a-g.

Árvore, até $22 \mathrm{~m}$ alt., ramos vegetativos glabros ou pubérulos, estípula e látex ausentes. Folhas 5-9 folioladas, pecíolo 1,8-2,3 cm compr., peciólulo não pulvinulado, 1-2 mm compr., folíolos cartáceos, elípticos, oblanceolados ou oblongos, 4,8-9,5 × 1,7-3,3 cm, base cuneada ou obliqua, ápice obtuso ou retuso, margem inteira, subrevoluta; venação broquidódroma, veias terciárias reticuladas; ambas as faces glabras ou pubérulas; domácias foveoladas, conspícuas. Tirso paniculiforme, eixos tomentosos, cincinos paucifloros, pedicelo floral 1,5-2 $\mathrm{mm}$ compr., brácteas ca. $1 \mathrm{~mm}$ compr., ovadas. Flores 2-3 mm compr.; sépalas pubescentes em ambas as faces; pétalas espatuladas, apêndice petalífero basal bipartido, maior que a pétala, bífido. Cápsula 2,3-2,7 × 2,2-2,5 cm, obtriangular, fortemente compressa lateralmente, ápice ligeiramente emarginado, 2-lobada, lobos agudos, estípite 7-9 mm compr., epicarpo glabro, endocarpo pubérulo; sementes obovoides, ca. $8 \times 5 \mathrm{~mm}$, arilo cobrindo os $2 / 3$ basais da semente.

Material selecionado: Arataca, PARNA Serra das Lontras, 21.VII.2005, fr., J. Jardim et al. 4705 (CEPEC). Camacan, RPPN Serra Bonita, 25.III.2007, fl., A.M. Amorim et al. 6973 (CEPEC).

Cupania ludowigii é endêmica no domínio Atlântico (Somner \& Ferrucci 2009) e diferenciase das outras espécies de Cupania deste estudo 
por possuir folíolos de margem inteira e revoluta, domácias foveoladas e cápsula obtriangular, fortemente compressa lateralmente, 2-lobada, lobos agudos. Coletada com flores em março e com frutos em julho.

2.3. Cupania racemosa (Vell.) Radlk., Sitzungsber. Math.-Phys. Cl. Königl. Bayer. Akad. Wiss. München 9: 568. 1879.

Fig. 2i-n

Árvore, até $18 \mathrm{~m}$ alt., ramos vegetativos glabros a pubescentes, estípula e látex ausentes. Folhas 8-10-folioladas, pecíolo $2-5,5 \mathrm{~cm}$ compr., peciólulo não pulvinulado, $2-10 \mathrm{~mm}$ compr., folíolos cartáceos, oblongos, elípticos, oblanceolados ou obovados, 6,8-12 × 2,9-4,4 $\mathrm{cm}$, base cuneada ou obliqua, ápice acuminado ou obtuso-acuminado, margem inteira, geralmente repanda; venação broquidódroma, veias terciárias reticuladas; ambas as faces glabras ou pubérulas; domácias foveoladas, conspícuas. Tirso paniculiforme, eixos tomentosos, cincinos paucifloros, pedicelo floral 1,2-1,5 mm compr., brácteas $2-4 \mathrm{~mm}$ compr., ovadas. Flores $4-5$ mm compr.; sépalas tomentosas em ambas as faces; pétalas espatuladas, apêndice petalífero basal bipartido, menor que a pétala, bífido. Cápsula 2-2,7 × 1,6-2,4 cm, trígono-obovoide, ápice apiculado, 3-lobada, lobos agudos, estípite 4-7 mm compr., epicarpo glabro a pubescente, às vezes levemente lenticelado, endocarpo tomentoso; sementes obovoides ou elipsoides, $14-17 \times 9-10 \mathrm{~mm}$, arilo cobrindo os $2 / 3$ basais da semente.

Material selecionado: Arataca, PARNA Serra das Lontras, 15.VI.2006, fr., A.M. Amorim et al. 6077 (CEPEC). Camacan, RPPN Serra Bonita, 25.X.2009, fr., R. Perdiz et al. 557 (CEPEC, CTES, HUEFS).

Endêmica no domínio Atlântico (Somner \& Ferrucci 2009), Cupania racemosa distingue-se das demais espécies amostradas de Cupania por possuir folhas 8-10-folioladas, folíolos glabros ou pubérulos de margem inteira, geralmente repanda e domácias foveoladas e conspícuas. Coletada com flores em maio e junho e com frutos em junho, agosto e outubro.

2.4 Cupania rugosa Radlk., Sitzungsber. Math.Phys. Cl. Königl. Bayer. Akad. Wiss. München 9: 563. 1879.

Fig. 2o-s

Árvore ou arbusto, até $20 \mathrm{~m}$ alt., ramos vegetativos tomentosos a vilosos, geralmente ferrugíneos, estípula e látex ausentes. Folhas 6-9-folioladas, pecíolo 2,5-16 cm compr., peciólulo não pulvinulado, 2-4 $\mathrm{mm}$ compr., folíolos cartáceos a subcoriáceos, bulado-rugosos, elípticos ou obovados, $10-25,5 \times 6-10,5 \mathrm{~cm}$, base cuneada ou arredondada, ápice obtuso, margem revoluta, subrepanda a levemente serrulada, dentes geralmente inconspícuos; venação craspedódroma mista, veias terciárias geralmente percurrentes; epifilo densamente tomentoso apenas nas veias, hipofilo viloso, indumento mais intenso nas veias primária e secundárias; domácias foveoladas, inconspícuas. Tirso paniculiforme, eixos viloso, cincinos paucifloros, pedicelo floral 1-1,6 mm compr., brácteas 4-4,5 mm compr., oblongoovadas. Flores 4-6 $\mathrm{mm}$ compr.; sépalas pubescentes a vilosas em ambas as faces; pétalas espatuladas, apêndice petalífero basal, bipartido, menor que a pétala, formando duas curtas linguetas. Cápsula 1,5-3,4 × 1,5-2,7 cm, trígono-obovoide, ápice apiculado, 3-lobada, lobos agudos, estípite 1-2 mm compr., epicarpo ferrugíneo-tomentoso, endocarpo viloso; semente não vista.

Material selecionado: Arataca, PARNA Serra das Lontras, 12.X.2008, fr., J. Jardim et al. 5409 (CEPEC). Camacan, RPPN Serra Bonita, 17.VI.2009, est., R. Perdiz et al. 723 (CEPEC).

Endêmica no domínio Atlântico (Somner \& Ferrucci 2009), Cupania rugosa distingue-se das demais espécies de Cupania deste estudo principalmente por características vegetativas. Possui folhas 6-9-folioladas, pecíolo alcançando até $16 \mathrm{~cm}$ compr., folíolos com 10-25,5 cm compr., venação terciária percurrente e presença de indumento tomentoso a viloso nos ramos vegetativos, hipofilo e eixos da inflorescência. Coletada com frutos em outubro.

\subsection{Cupania sp. 1}

Fig. 2f-h

Árvore, até $10 \mathrm{~m}$ alt., ramos vegetativos glabros a pubérulos, estípula e látex ausentes. Folhas 4-5-folioladas, pecíolo 3-4,5 cm compr., peciólulo não pulvinulado, 3-5 mm compr., folíolos cartáceos a subcoriáceos, obovados, elípticos ou oblongos, 9,8-11 × 3,5-4,4 cm, alternos ou subopostos, base cuneada, ápice acuminado-obtuso, margem inteira; venação broquidódroma, veias terciárias não percurrentes; ambas as faces glabriúsculas; domácias foveoladas, conspícuas. Tirso paniculiforme, eixos pubérulos a tomentosos, brácteas caducas. Flores não vistas. Cápsula ca. $2,1 \times 2,5 \mathrm{~cm}$, trígonoobovoide, ápice obtuso, 3-lobada, lobos obtusos ou arredondados, estípite ca. $5 \mathrm{~mm}$ compr., epicarpo 
glabriúsculo, endocarpo viloso; semente não vista. Material examinado: Barro Preto, Serra da Pedra Lascada, 11.XI.2004, fr., P. Fiaschi et al. 2647 (CEPEC).

Cupania sp. 1 não possui documentação adequada que permita o reconhecimento de sua identidade específica. Diferencia-se das outras espécies de Cupania deste estudo por apresentar pecíolo, raque e folíolos glabros, folhas 4-5-folioladas, folíolos elípticos com margem inteira, cápsula trígono-obovoide, epicarpo glabriúsculo. Coletada com frutos em novembro.

3.1. Matayba guianensis Aubl., Hist. Pl. Guiane fr. 1: 331, t. 128. 1775. Iconografia: Ferrucci (2006), fig. 3d; Silva et al. (2013), fig. $2 \mathrm{~h}$.

Árvore ou arbusto, até $20 \mathrm{~m}$ alt., ramos vegetativos glabros a pubérulos, estípula e látex ausentes. Folhas 8-24-folioladas, pecíolo 2,5-5,2 $\mathrm{cm}$ compr., peciólulo não pulvinulado, 5-8 mm compr., folíolos cartáceos, elípticos, oblongos, ovados ou obovados, geralmente conduplicados e recurvados, $8,2-13 \times 3,0-6,1 \mathrm{~cm}$, base cuneada, ápice retuso, obtuso a obtuso-acuminado, margem inteira, revoluta; venação broquidódroma, veias primária e secundária proeminentes no hipofilo, as secundárias arqueado-ascendentes no terço proximal, pouco proeminentes no epifilo; ambas as faces glabras a pubescentes; domácias urceoladas, geralmente uma a duas por folíolo, raro mais de duas. Tirso paniculiforme, eixos pubescentes a tomentosos, dicásios paucifloros, pedicelo floral 1-1,6 mm compr., brácteas ca. $3 \mathrm{~mm}$ compr., linear-lanceoladas. Flores 4-5 mm compr.; cálice gamossépalo com abertura precoce, sépalas pubescentes em ambas as faces; pétalas oblongas, apêndice petalífero basal, bipartido, menor ou de mesmo comprimento que a pétala, bífido. Cápsula 1,5-1,9 × 1,6-2 cm, globosa, estípite 1-2 $\mathrm{mm}$ compr., epicarpo pubérulo, subverrucoso, endocarpo tomentoso; sementes elipsoides, 10-15 $\times$ 6-8 $\mathrm{mm}$, arilo cobrindo mais da metade da semente.

Material selecionado: Camacan, RPPN Serra Bonita, 23.I.2007, fr., R. Borges et al. 671 (CEPEC).

Matayba guianensis é amplamente distribuída na América do Sul, possuindo registros na Bolívia, Equador, Guiana Francesa, Suriname, Peru, Venezuela e Brasil (Somner et al. 2009b), ocorrendo em quase todos os estados brasileiros (Somner et al. 2014). Distingue-se entre as espécies do gênero que ocorrem no domínio Atlântico (ca. 15 espécies) por apresentar folíolos geralmente conduplicados e recurvados, e veias secundárias arqueado-ascendentes no terço proximal, pouco proeminentes no epifilo. Coletada com frutos em janeiro.

3.2 Matayba intermedia Radlk. in Mart., Eichl. \& Urban, Fl. Bras. 13(3): 619. 1900. Iconografia: Somner et al. (2009a), fig. 2a-f; Silva et al. (2013), fig. $2 \mathrm{j}$.

Árvore, até $19 \mathrm{~m}$ alt., ramos vegetativos glabros a pubescentes, estípula e látex ausentes. Folhas 4-10-folioladas, pecíolo 2,5-5,5 cm compr., peciólulo não pulvinulado, 5-9 mm compr., folíolos cartáceos, elípticos, obovados ou ovados, não conduplicados e recurvados, 7,5-14,5 × 2,7-5,5 cm, base obliqua, cuneada ou obtusa, ápice agudo, obtuso ou acuminado, margem inteira; venação broquidódroma, veias secundárias obliquas e retilíneas no terço proximal, levemente arqueadas no terço distal, não proeminentes no epifilo, veias terciárias levemente proeminentes no epifilo; ambas as faces glabrescentes; domácias ausentes. Tirso paniculiforme, eixos pubescentes a tomentosos, dicásios paucifloros, pedicelo floral 1-2 mm compr., brácteas ca. $1 \mathrm{~mm}$ compr., ovadas. Flores 3-5 mm compr.; cálice gamossépalo com abertura precoce, sépalas tomentosas em ambas as faces; pétalas obovadas, apêndice petalífero basal bipartido, mesmo comprimento das pétalas. Cápsula 0,8-1,4 × 0,5-0,9 cm, globosa, estípite 1-2 mm compr., epicarpo pubérulo, endocarpo viloso; sementes elipsoides, 7-9 × 5-6 mm, arilo cobrindo os $2 / 3$ basais da semente.

Material selecionado: Barro Preto, Serra da Pedra Lascada, 2.XI.2003, fl., P. Fiaschi et al. 1819 (CEPEC).

Endêmica no domínio Atlântico (Somner \& Ferrucci 2009), com registros para a Região Sul e os estados do Rio de Janeiro e São Paulo, Matayba intermedia é registrada pela primeira vez para a Região Nordeste. Ver comentários em M. guianensis sobre a distinção dessas espécies. Coletada com flores em outubro e novembro; frutos em novembro.

4.1 Paullinia carpopoda Cambess. in A.St.-Hil., Fl. Bras. Merid. 1: 376, t. 78 B. 1828. Iconografia: Ferrucci (2006), fig. 2a-b; Silva et al. (2013), fig. 3a-b.

Liana, latescente, ramos vegetativos e reprodutivos tomentosos, estípulas lanceoladas, caducas. Folhas 7-9-folioladas, 3-4-jugas, 
folíolos basais ternados, pecíolo $2-5,5 \mathrm{~cm}$ compr., peciólulos 1-2 mm compr., raque alada ou marginada; folíolos cartáceos, elípticos, oblanceolados ou obovados, terminais 5,7-10,7 $\times 1,5-3,2 \mathrm{~cm}$, base acuminada a cuneada, ápice acuminado e mucronado, margem inteira; venação broquidódroma; ambas as faces pubescentes a tomentosas quando jovens, glabrescentes quando adultos; domácias barbadas, conspícuas. Tirso racemi- ou paniculiforme, eixos densamente tomentosos, cincinos plurifloros, pedicelo floral ca. $3 \mathrm{~mm}$ compr., brácteas ca. 0,8 mm compr., ovadas. Flores 4,5-6 mm compr.; sépalas 4, face abaxial tomentosa, adaxial pubescente, pétalas obovadas, apêndices petalíferos com crista emarginada. Cápsula globosa, sem alas, 1,2-1,7 × 1,2-1,7 $\mathrm{cm}$, estípite ca. $12 \mathrm{~mm}$ compr., ápice apiculado, epicarpo e endocarpo glabros, epicarpo 6-costado; semente 1 , subglobosa ou elipsoide, ca. $10 \times 10$ $\mathrm{mm}$, arilo cobrindo mais de $2 / 3$ ou toda a semente. Material selecionado: Arataca, PARNA Serra das Lontras, 12.IX.2009, fr., R. Perdiz et al. 519 (CEPEC, CTES, HUEFS). Barro Preto, Serra da Pedra Lascada, 22.V.2010, fr., R. Perdiz et al. 701 (CEPEC, CTES, HUEFS). Camacan, RPPN Serra Bonita, 17.VI.2009, fr., R. Perdiz et al. 402 (CEPEC).

Paullinia carpopoda ocorre nos domínios Atlântico e do Cerrado no Brasil (Somner et al. 2014) e pode ser confundida com $P$. ferruginea ou $P$. unifoliolata por compartilhar com ambas as cápsulas globosas. No entanto, elas diferem em aspectos vegetativos. Paullinia ferruginea possui folhas 5-folioladas densamente ferrugíneotomentosas no hipofilo, $P$. unifoliolata possui folhas 1-folioladas e glabras (estado de caráter único no gênero), enquanto $P$. carpopoda possui folhas 7-9-folioladas, pubescentes a tomentosas. Coletada com flores entre março a abril; frutos em junho, setembro e outubro.

4.2 Paullinia ferruginea Casar., Nov. Stirp. Bras. Dec. 3: 28. 1842. Fig. 3a-d

Liana, latescente, ramos vegetativos e reprodutivos ferrugíneo-tomentosos, estípulas subuladas, caducas. Folhas 5-folioladas, 2-jugas, pecíolo 5-8,7 cm compr., peciólulo 4-12 mm compr., raque sem alas, folíolos cartáceos, ovados ou ovado-lanceolados, terminais 8,6-12 $\times 4,1-5,3 \mathrm{~cm}$, base obliqua ou arredondada, ápice acuminado, margem denticulada a crenado-serrada, dentes obtusos; venação craspedódroma mista, veias terciárias percurrentes, obliquas; ambas as faces densamente ferrugíneo-tomentosas, apenas nas veias primária e secundária no epifilo; domácias barbadas, inconspícuas. Tirso racemiou paniculiforme, eixos densamente ferrugíneotomentosos, cincinos plurifloros, pedicelo floral 2,5-4 mm compr., brácteas ca. $2 \mathrm{~mm}$ compr., ovadas. Flores ca. $4 \mathrm{~mm}$ compr., sépalas 5, face adaxial glabra, face abaxial pubescente a tomentosa, pétalas oblongas, apêndice petalífero com crista inteira. Cápsula elipsoide ou globosa, sem alas, 1,5-2,6 × 1,2-1,9 cm, estípite 2-6 mm compr., ápice apiculado, epicarpo ferrugíneotomentoso, rugoso quando seco, endocarpo pubescente; semente 1 , obovoide, $10-14 \times 8-10$ $\mathrm{mm}$, arilo cobrindo metade da semente.

Material selecionado: Camacan, RPPN Serra Bonita, 5.VI.2006, fr., M. Lopes et al. 777 (CEPEC).

Disjunta entre os domínios Atlântico e Amazônico (Somner et al. 2014) e restrita ao Brasil, Paullinia ferruginea é conhecida por apenas uma amostra em uma das áreas de estudo. Também possui poucas amostras nas coleções dos herbários baianos, com apenas cinco espécimes no CEPEC. Ver comentários em $P$. carpopoda. Frutos coletados em junho.

4.3 Paullinia micrantha Cambess. in A.St.-Hil.., Flor. Bras. Merid. 1: 373, $1825 . \quad$ Fig. 3e-h

Liana, latescente, ramos vegetativos e reprodutivos glabros ou pubescentes, estípulas não vistas. Folhas 7-9-folioladas, 3-(4)-jugas, folíolos basais ternados; pecíolo $3,5-7,7 \mathrm{~cm}$, peciólulos ca. $0,6 \mathrm{~cm}$ na juga inferior, folíolos sésseis nas jugas superiores, raque marginada ou alada, folíolos cartáceos, elípticos ou subrômbicos, terminais 7,5-8,7 $\times 3-3,3 \mathrm{~cm}$, base decurrente, ápice agudo, raro acuminado, margem revoluta, dentado-serrada a partir da metade do folíolo; venação craspedódroma mista, venação terciária não percurrente; ambas as faces pubescentes, indumento restrito às veias no epifilo; domácias barbadas, conspícuas. Tirso espiciforme, eixos pubescentes, cincinos paucifloros, pedicelo floral ca. 1,5 mm compr., brácteas ca. 0,8 mm compr., ovadas. Flores 3-3,5 mm compr.; sépalas 4, face abaxial tomentosa, face adaxial glabra, pétalas obovadas ou espatuladas, apêndices petalíferos com crista bilobada. Cápsula trígono-obovoide, 3-alada, alas pouco desenvolvidas, 1,5-1,8 $\times$ 0,8-1 cm, estípite 1-2 mm compr., ápice apiculado, epicarpo e endocarpo glabros; sementes (1-2)-3, trígono-obovoides, ca. $7 \times 6 \mathrm{~mm}$, arilo cobrindo mais de $3 / 4$ do compr. da semente. 

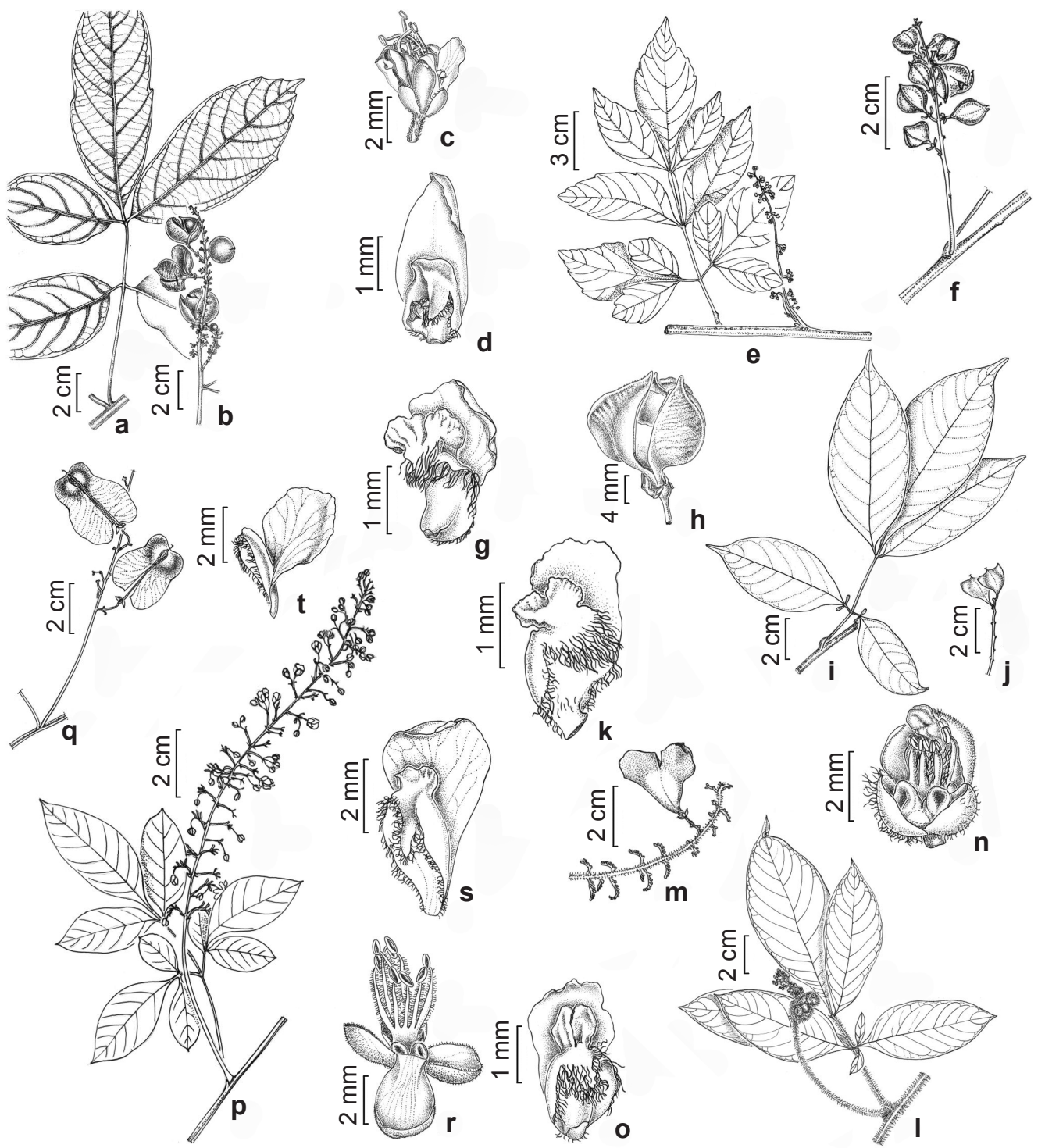

Figura 3 - a-d. Paullinia ferruginea - a. ramo vegetativo; b. ramo com cápsulas maduras; c. flor estaminada; d. face adaxial da pétala posterior, evidenciando apêndice petalífero. e-h. Paullinia micrantha - e. ramo com flores; f. ramo com frutos; g. face adaxial da pétala posterior, evidenciando apêndice petalífero; h. cápsula madura expondo parcialmente uma semente arilada. i-k. Paullinia racemosa - i. ramo vegetativo; j. ramo com frutos imaturos; k. face adaxial da pétala posterior, evidenciando apêndice petalífero. 1-o. Paullinia revoluta - 1. ramo com flores; $\mathrm{m}$. ramo com cápsula madura; n. flor pistilada desprovida da sépala posterior e da corola, evidenciando os lobos nectaríferos; o. face adaxial da pétala posterior, evidenciando apêndice petalífero. p-t. Serjania salzmanniana - p. ramo com flores; q. ramo com frutos; r. flor estaminada desprovida da corola, evidenciando lobos nectaríferos; s. face adaxial da pétala posterior, evidenciando apêndice petalífero; t. face adaxial da pétala anterior evidenciando apêndice petalífero. (a-d Paixão 51; e, g Sylvestre 997; f, h Fernandes 779; i-j Perdiz 421; k Santos 288; 1, n-o Perdiz 564; m Perdiz 487; p, r-t Carvalho 7006; q Cardoso 1636). Figure 3 - a-d. Paullinia ferruginea - a. sterile branch; b. branch with mature capsules; c. staminate flowers; d. adaxial view of posterior petal showing adnate appendage. e-h. Paullinia micrantha - e. branch with flowers; f. branch with fruits; g. adaxial view of posterior petal, showing adnate appendage; h. mature capsule, partially exposing an arillate seed. i-k. Paullinia racemosa - i. sterile branch; j. branch with fruits showing immature capsules; $\mathrm{k}$. adaxial view of posterior petal showing adnate appendage. 1-o. Paullinia revoluta -1. branch with flowers; $\mathrm{m}$. branch with mature capsule; $\mathrm{n}$. pistillate flower devoid of posterior sepal and corolla, showing nectary lobes; o. adaxial view of posterior petal, showing adnate appendage. p-t. Serjania salzmanniana - p. branch with flowers; q. branch with fruits; r. staminate flower devoid of corolla, showing nectary lobes; s. adaxial view of posterior petal showing adnate appendage; t. adaxial view of anterior petal, showing adnate appendage. (a-d Paixão 51; e, g Sylvestre 997; f, h Fernandes 779; i-j Perdiz 421; k Santos 288; 1, n-o Perdiz 564; m Perdiz 487; p, r-t Carvalho 7006; q Cardoso 1636). 
Material selecionado: Arataca, PARNA Serra das Lontras, 24.II.2010, est., R. Perdiz et al. 642 (CEPEC). Camacan, RPPN Serra Bonita, 5.VI.2006, fl., M. Lopes et al. 800 (ALCB, CEPEC, HUEFS).

Endêmica no domínio Atlântico (Somner et al. 2014), Paullinia micrantha compartilha com P. carpopoda as folhas 7-9-folioladas, diferindo desta por apresentar folíolos com margem dentadoserrada (vs. margem inteira) e cápsulas com alas (vs. cápsulas globosas). Coletada com flores em junho.

4.4 Paullinia racemosa Wawra, Oesterr. Bot. Z. 29: 215.1879

Fig. 3i-k

Liana, latescente, ramos vegetativos e reprodutivos glabros, estípulas ovadas, caducas. Folhas 5-folioladas, 2-jugas, geralmente com um par de foliólulos basais extremamente reduzidos nos folíolos da juga inferior; pecíolo 1,3-6 cm compr., peciólulo 2-4 $\mathrm{mm}$ compr., raque sem alas, folíolos cartáceos, elípticos, obovados ou lanceolados, terminais 10,5-11,1 × 3,8-3,9 cm, base cuneada, ápice acuminado, margem inteira; venação broquidódroma; ambas as faces glabras; domácias barbadas, conspícuas. Tirso espiciforme, eixos pubescentes, cincinos plurifloros, pedicelo floral ca. 1,5 mm compr., brácteas ca. 1,5 mm compr., ovado-lanceoladas. Flores 3-3,3 mm compr.; sépalas 4, ambas as faces pubescentes, pétalas obovado-oblongas, apêndice petalífero com crista erosa ou emarginada. Cápsula trígonoobovoide, 3-alada, alas bem desenvolvidas, margens inflexas, 1,2-2 × 0,6-0,9 cm, estípite ca. $2 \mathrm{~mm}$ compr., atenuada na base, ápice truncado, epicarpo glabro, endocarpo tomentoso na margem das valvas; sementes (1-2)-3, ovoides, ca. $8 \times 6$ $\mathrm{mm}$, arilo cobrindo metade da semente

Material selecionado: Arataca, PARNA Serra das Lontras, 12.IV.2007, fl., M. Lopes et al. 1185 (CEPEC). Camacan, RPPN Serra Bonita, 19.VI.2009, fr., R. Perdiz et al. 421 (CEPEC, CTES).

Endêmica no Brasil (Somner et al. 2014), Paullinia racemosa é facilmente distinguível das outras espécies de Paullinia de cápsulas aladas por apresentar ramos vegetativos e reprodutivos glabros e folhas 5-folioladas, geralmente com um par de foliólulos reduzidos na base dos folíolos inferiores. Coletada com flores em março e abril; frutos em junho.

4.5 Paullinia revoluta Radlk., Monogr. Paullinia: 251. 1895.

Fig. 31-o

Liana, latescente, ramos vegetativos e reprodutivos velutinos, estípulas linear-lanceoladas, geralmente persistentes. Folhas 5-folioladas, 2-jugas, folíolos basais geralmente ternados, pecíolo 1-3,5 cm compr., peciólulo 1-2 mm compr., raque sem alas ou marginada, folíolos cartáceos, elípticos, obovados ou oblongo-lanceolados, terminais $8-9 \times 3,1-4,1 \mathrm{~cm}$, base cuneada ou atenuada no folíolo terminal, obliqua nos folíolos laterais, ápice acuminado, margem inteira, revoluta; venação broquidódroma, venação terciária não percurrente; epifilo glabro a densamente velutino, hipofilo densamente velutino; domácias ausentes. Tirso espiciforme, eixos velutinos, cincinos plurifloros, pedicelo floral ca. $7 \mathrm{~mm}$ compr., brácteas 0,5-1 mm compr., lanceoladas. Flores 5-6 mm compr.; sépalas 5 , ambas as faces tomentosas, pétalas obovadas, apêndice petalífero com crista emarginada. Cápsula trígono-obovoide, 3-alada, alas bem desenvolvidas, margens planas, 2,1-3,4 $\times 2,5 \mathrm{~cm}$ compr., estípite ca. $1 \mathrm{~mm}$ compr., base cuneada, ápice retuso a emarginado, epicarpo velutino, endocarpo tomentoso, sementes 1-2, obovoides, ca. $14 \mathrm{~mm}$ compr., arilo cobrindo a metade da semente.

Material selecionado: Arataca, PARNA Serra das Lontras, 13.VIII.2009, fr., R. Perdiz et al. 487 (CEPEC, CTES, HUEFS).

Paullinia revoluta é endêmica no domínio Atlântico (Somner et al. 2009a) e distingue-se das demais espécies de Paullinia amostradas por possuir ramos vegetativos velutinos e cápsula 3-alada com alas de margem plana. É uma espécie comumente encontrada em cotas altitudinais mais baixas, geralmente litorâneas, tendo sido coletada apenas no PARNA Serra das Lontras na cota altitudinal limiar (ca. $600 \mathrm{~m}$ ) entre as florestas montana e submontana na Região Nordeste brasileira. Coletada com flores em fevereiro; frutos, em agosto.

4.6 Paullinia rubiginosa Cambess., Fl. Bras. Merid. 1: 371. 1825. Iconografia: AcevedoRodríguez (2002), fig. 285a-m.

Liana, latescente, ramos vegetativos e reprodutivos híspidos, estípulas ovadas, escariosas, persistentes. Folhas 5-folioladas, 2-jugas, pecíolo 5-13,2 cm compr., peciólulo 0,2-1,5 cm compr., raque sem alas, folíolos cartáceos, obovados, oblanceolados, elípticos, ovados ou lanceolados, terminais 8,3-17,5 $\times 3-6,3 \mathrm{~cm}$, base cuneada, obliqua nos folíolos laterais, ápice agudo a acuminado, margem ciliada, serrada; venação craspedódroma, venação terciária percurrente obliqua; ambas as faces 
densamente hirsutas; domácias inconspícuas. Tirso espiciforme, eixos tomentosos, cincinos plurifloros, pedicelo floral 2-3,5 mm compr., brácteas ca. 3,5 mm compr., linear-lanceoladas. Flores 4-5 mm compr.; sépalas 5, ambas as faces pubérulas, pétalas espatuladas, apêndice petalífero com crista emarginada ou bilobada. Cápsula elipsoide ou obovoide, sem alas, 1,7-2 × 0,5-0,9 cm, estípite ca. 1 mm compr., ápice acuminado, epicarpo densamente setoso-hirsuto, endocarpo pubescente, epicarpo 6-costado; sementes (1-2)-3, elipsoides, 10-15 × 6-9 mm, arilo cobrindo até metade da semente.

Material selecionado: Arataca, PARNA Serra das Lontras, 6.II.2009, fl., R. Perdiz et al. 298 (CEPEC). Barro Preto, Serra da Pedra Lascada, 22.V.2010, fl., $R$. Perdiz et al. 699 (CEPEC, CTES). Camacan, RPPN Serra Bonita, 22.I.2007, fl., R. Borges et al. 638 (CEPEC).

Paullinia rubiginosa possui ampla distribuição geográfica, disjunta entre os domínios Atlântico e Amazônico (Somner et al. 2014), e se diferencia das demais espécies amostradas de Paullinia por apresentar indumento hirsuto nas folhas e inflorescências, setoso-hirsuto no epicarpo, estípulas ovadas, escariosas e persistentes, folhas 5-folioladas e cápsula elipsoide ou obovoide sem alas. Floresce em janeiro, fevereiro e em maio, frutifica em fevereiro e março.

4.7 Paullinia unifoliolata Perdiz \& Ferrucci, Brittonia 64(2): 114-118. 2012. Iconografia: Perdiz et al. (2012), fig. 1a-i.

Liana, latescente, ramos vegetativos e reprodutivos glabros, estípulas ovadas, caducas. Folhas 1-folioladas, pecíolo 1-4,2 cm compr., peciólulo 3-7 $\mathrm{mm}$ compr., folíolos cartáceos, elípticos a obovados, 7,4-21 × 3,5-9 cm; base cuneada ou obtusa, raro obliqua, ápice acuminado-obtuso a retuso, margem inteira; venação broquidódroma, venação terciária não percurrente; faces glabras; domácias ausentes. Tirso racemiforme, eixos pilosos, cincinos plurifloros, pedicelo floral 2,5-4 mm compr., brácteas 0,5-1 mm compr., ovadas. Flores 3,5-4 mm compr.; sépalas 5, face abaxial pilosa, adaxial glabra, pétalas obovadas a espatuladas, apêndice petalífero com crista emarginada ou biauriculiforme. Cápsula globosa, sem alas, 1,6-2,4 × 1,2-1,8 cm, estípite 1-3 mm compr., base atenuada, ápice apiculado, epicarpo glabro com três cristas longitudinais bem destacadas, endocarpo densamente ferrugíneopiloso; semente 1, obovoide-subesférica, 12-19 $\times 10-16 \mathrm{~mm}$, arilo cobrindo metade da semente.
Material selecionado: Arataca, PARNA Serra das Lontras, 14.IV.2006, fr., A.M. Amorim et al. 5761 (holótipo, CEPEC; isótipo, CTES).

Paullinia unifoliolata é endêmica no domínio Atlântico, restrita ao estado da Bahia nos municípios de Arataca e Una (Perdiz et al. 2012), e caracterizase principalmente pelas folhas 1-folioladas, estado de caráter único no gênero. Ver comentários em $P$. carpopoda para distinção específica entre espécies similares. Coletada com flores em novembro; frutos, de abril a junho e em dezembro.

5.1 Serjania communis Cambess. in A.St.-Hil., Fl. Bras. Merid. 1: 362. 1828. Iconografia: AcevedoRodríguez \& Beck (2005), fig. 65.

Trepadeira semilenhosa, latescente, ramos vegetativos e reprodutivos glabriúsculos, corte transversal do caule com cilindro vascular composto, três cilindros vasculares periféricos e equidistantes, ao redor de uma medula oca, ângulos obtusos entre os cilindros, estípulas ovadas, persistentes. Folhas biternadas, pecíolo 3,8-5 cm compr., peciólulo terminal ca. 1,4 cm compr., raque primária marginada, folíolos subcartáceos, elípticos, ovados ou rômbicos, terminais da juga superior ca. $6 \times 2,6 \mathrm{~cm}$, base decurrente, ápice agudo ou acuminado, margem dentada; venação craspedódroma; faces glabriúsculas. Tirso racemiforme, eixos pubescentes, cincinos paucifloros, pedicelo floral 1,5-2 $\mathrm{mm}$ compr., brácteas 1-1,5 mm compr., ovadas. Flores ca. $5 \mathrm{~mm}$ compr.; sépalas 4 , ambas as faces pubérulas, ciliadas, pétalas obovadas, ambas as faces glabras, apêndice petalífero com crista bipartida. Samarídeo esquizocárpico ovado a subcordado, cartáceo, mericarpo 1,8-2,5 × 0,5-1 cm, lóculos complanados, 3-4 mm larg., presença de ala dorsal, ca. $1 \mathrm{~mm}$ larg., emarginado no ápice, ala não constrita na base do lóculo, epicarpo pubescente, endocarpo viloso; sementes elipsoides, complanadas lateralmente, ca. $7 \times 7 \mathrm{~mm}$.

Material selecionado: Arataca, PARNA Serra das Lontras, 5.VIII.2006, fl., M. Lopes et al. 982 (CEPEC).

Espécie de ampla distribuição na América do Sul (Acevedo-Rodríguez 1993) e disjunta entre os domínios Amazônico e Atlântico (Somner et al. 2014), Serjania communis se distingue de $S$. salzmanniana por ser uma trepadeira semilenhosa (vs. liana), corte transversal do caule apresentar três cilindros vasculares periféricos ao redor uma medula oca (vs. cilindro vascular simples, 5-lobado), folíolos de margem dentada (vs. 
folíolos de margem inteira, às vezes com dentes inconspícuos), sepálas 4 (vs. sépalas 5) e mericarpo $1,8-2,5 \times 0,5-1 \mathrm{~cm}$ (vs. mericarpo 3,8-4,4 $\times$ $1,3-1,5)$. Coletada com flores em agosto.

5.2 Serjania salzmanniana Schltdl., Linnaea 18: 46 (err. typ. 62). $1844 . \quad$ Fig. 3p-t

Liana, latescente, ramos vegetativos e reprodutivos pubescentes, corte transversal do caule com cilindro vascular simples, 5-lobado, lobos arredondados, estípulas ovadas, persistentes. Folhas biternadas, pecíolo 2,5-7,5 cm compr., peciólulo do folíolo terminal 2-4 mm compr., raque primária sem alas, folíolos cartáceos, rômbicos, ovados, elípticos ou lanceolados, terminais da juga superior 8,2-9,1 ×3,7$5 \mathrm{~cm}$, base decurrente, ápice acuminado ou obtuso, margem inteira, às vezes com dentes inconspícuos; venação broquidódroma; ambas as faces pubescentes, indumento restrito às veias no epifilo. Tirso racemiou paniculiforme, eixos pubescente, cincinos plurifloros, pedicelo floral 4-5 $\mathrm{mm}$ compr., brácteas 0,6-0,9 mm compr., ovadas. Flores 5-7 mm compr.; sépalas 5 , ambas as faces pubérulas a tomentosas, pétalas obovadas ou espatuladas, ambas as faces glabras, apêndice petalífero com crista emarginada ou bilobada. Samarídeo esquizocárpico ovado a cordado, cartáceo, mericarpo 3,8-4,4 × 1,3-1,5 cm, lóculos complanados, 10-12 mm larg., presença de ala dorsal, 3-4,2 $\mathrm{mm}$ larg., emarginado no ápice, ala não constrita na base do lóculo, epicarpo piloso, endocarpo pubescente; sementes obovoides, complanadas lateralmente, ca. $6 \times 4,5 \mathrm{~mm}$.

Material selecionado: Barro Preto, Serra da Pedra Lascada, 16.I.2007, fl. efr., R. Borges et al. 506 (CEPEC).

Serjania salzmanniana possui distribuição restrita ao Brasil e disjunta entre os domínios Atlântico e Amazônico (Somner et al. 2014). Ver comentários em $S$. communis. Coletada com flores em novembro e janeiro e com frutos em novembro.

6.1 Talisia macrophylla (Mart.) Radlk., Sitzungsber. Math.-Phys. Cl. Königl. Bayer Akad. Wiss München 8: 347. 1878. Iconografia: AcevedoRodríguez (2003), fig. 87a-e.

Árvore, até $12 \mathrm{~m}$ alt., ramos vegetativos glabros. Folhas 7-12-folioladas, pecíolo 16-23,5 $\mathrm{cm}$ compr., peciólulo pulvinulado, dilatado, 6-15 mm compr., folíolos cartáceos a coriáceos, elípticos ou oblongos, falcados, $12-57,2 \times 4,7-16,3$ $\mathrm{cm}$, base obliqua, ápice agudo a acuminado, margem inteira, ligeiramente revoluta; venação broquidódroma; faces glabras; domácias ausentes.
Tirso paniculiforme, eixos pubescentes a tomentosos, presença de catafilos na base, dicásios simples, pedicelo floral ca. $2 \mathrm{~mm}$ compr., brácteas ca. $2 \mathrm{~mm}$ compr., ovado-lanceoladas. Flores 4-7 mm compr., sépalas pubérulas na face abaxial, pétalas oblongas ou espatuladas, apêndice petalífero basal simples, mesmo comprimento da pétala, ápice bífido. Fruto bacáceo, 1,6-3 ×1,5-1,9 cm, elipsoide ou globoso, arredondado no ápice, apiculado, epicarpo glabrescente; sementes subesféricas a elipsoides, ca. $19 \times 16 \mathrm{~mm}$, sarcotesta envolvendo toda a semente. Material selecionado: Arataca, PARNA Serra das Lontras, 12.IX.2011, fl., R. Perdiz et al. 939 (CEPEC).

Talisia macrophylla é comumente identificada como T. cerasina (Benth.) Radlk. nos herbários. Acevedo-Rodríguez (2003) considera $T$. macrophylla como de ocorrência restrita ao domínio Amazônico, apesar do material tipo ser proveniente de Ilhéus, Bahia. Por outro lado, T. cerasina, descrita originalmente para o Pará (Acevedo-Rodríguez 2003), é comumente a determinação taxonômica encontrada em vários materiais provenientes da Bahia (e.g., Carvalho 3624; Folli 1043; Mori 9303). A análise das fotos do tipo nomenclatural (Martius 483) e de coleções de herbário permite afirmar que T. macrophylla ocorre no domínio Atlântico, tratando-se de espécie relativamente comum no sub-bosque das florestas ombrófilas no sul da Bahia. Talisia macrophylla é vegetativamente similar a $T$. cerasina, diferindo desta por caracteres florais: em T. macrophylla as flores apresentam 5 estames (vs. 8 estames), e disco nectarífero e ovário glabros (vs. pilosos). Coletada com flores em setembro.

\section{Agradecimentos}

Os autores agradecem ao $\mathrm{CNPq}$, a concessão da bolsa de mestrado a ROP (processo 131311/20093/GM) e bolsa de Produtividade concedida a AMA (processo 306992/2012-4), além do financiamento obtido no Edital Universal 2009; à FAPESB, o Edital de Pesquisas 2009; ao Sr. Vitor Becker e Clemira Souza, proprietários da RPPN Serra Bonita, o auxílio logístico; ao IESB, o apoio logístico no acesso ao Complexo Serra das Lontras; à equipe do herbário CEPEC, o auxílio nas viagens de campo; a Laura Simón e Liliana Gómez, as belíssimas ilustrações; aos funcionários, pesquisadores e bolsistas do IBONE-CTES, a hospitalidade; ao PPGBOT/UEFS e CEPEC, a infraestrutura concedida; ao Dr. Milton Groppo, Dr. Luciano Paganucci de Queiroz e a dois revisores anônimos, as sugestões feitas ao manuscrito. 


\section{Referências}

Acevedo-Rodríguez, P. 1993. Systematics of Serjania (Sapindaceae). Part I: A revision of Serjania sect. Platycoccus. Memoirs of the New York Botanical Garden 67.93p.

Acevedo-Rodríguez, P. 2002. Sapindaceae. In: Mori, S.A.; Cremers, G.; Gracie, C.A.; de Granville, J.J.; Heald, S.V.; Hoff, M. \& Mitchell, J.D. (eds.). Guide to the vascular plants of Central French Guiana. Part 2. Dicotyledons. The New York Botanical Garden Press, New York. Pp. 656-669.

Acevedo-Rodríguez, P. 2003. Melicocceae (Sapindaceae): Melicoccus and Talisia. Flora Neotropica 87: 1-178.

Acevedo-Rodríguez, P. 2011. Allophylastrum: a new genus of Sapindaceae from northern South America. Phytokeys 5: 39-43.

Acevedo-Rodríguez, P. 2012. Alatococcus, a new genus of Sapindaceae from Espirito Santo, Brazil. Phytokeys 10: $1-5$.

Acevedo-Rodríguez, P. \& Beck, H.T. 2005. Sapindaceae. In: Steyermark, J.A.; Berry, P.E.; Yatskievych, K. \& Holst, B.K. (eds.). Flora of the Venezuelan Guayana. Vol. 9. Missouri Botanical Garden Press, St. Louis. Pp. 45-88.

Amorim, A.M.; Jardim, J.G.; Lopes, M.M.M.; Fiaschi, P.; Borges, R.A.X.; Perdiz, R.O. \& Thomas, W.W. 2009. Angiospermas em remanescentes de floresta montana no sul da Bahia, Brasil. Biota Neotropica 9: 313-348.

Buerki, S.; Lowry II, P.P.;Alvarez, N.; Razafimandimbison, S.G.; Küpfer, P. \& Callmander, M.W. 2010. Phylogeny and circumscription of Sapindaceae revisited: molecular sequence data, morphology and biogeography support recognition of a new family, Xanthoceraceae. Plant Ecology and Evolution 143: 148-159.

Coelho, M.M. \& Amorim, A.M. 2014. Composição florística em Floresta Montana no eixo AlmadinaBarro Preto, sul da Bahia, Brasil. Biota Neotropica 14: 1-41.

Coutinho, L.M. 2006. O conceito de bioma. Acta Botanica Brasilica 20: 13-23.

Ferrucci, M.S. 1995. Sapindaceae. In: Stannard, B.L. (ed.). Flora of the Pico das Almas, Chapada Diamantina, Brazil. Royal Botanic Gardens, Kew. Pp. 581-585.

Ferrucci, M.S. 2006. Flora de Grão-Mogol, Minas Gerais: Sapindaceae. Boletim de Botânica da Universidade de São Paulo 24: 79-86.

Ferrucci, M.S. \& Coulleri, J.P. 2013. Serjania lucianoi (Sapindaceae: Paullinieae), a new species from Northern Bahia, Brazil. Systematic Botany 38: 172-177.

Ferrucci, M.S. \& Somner, G.V. 2005. Sapindaceae do Morro do Pai Inácio e Serra da Chapadinha, Chapada Diamantina, Bahia, Brasil. Revista de Biologia Neotropical 2: 15-26.
Ferrucci, M.S.; Somner, G.V. \& Rosa, M.M.T. 2009. Allophylus. In: Martins, S.E.; Wanderley, M.G.L.; Shepherd, G.J.; Giulietti, A.M. \& Melhem, T.S. (eds.). Flora fanerogâmica do estado de São Paulo. Vol. 6. Instituto de Botânica, São Paulo. Pp. 197-200.

Font Quer, P. 1965. Diccionario de botánica. Ed. Labor, Barcelona. 1244p.

Giulietti, A.M.; Queiroz, L.P.; Silva, T.R.S.; França, F.; Guedes, M.L. \& Amorim, A.M. 2006. Flora da Bahia. Sitientibus Série Ciências Biológicas 6: 169-173.

Leitman, P.; Amorim, A.; Menini Neto, L. \& Forzza, R.C. 2014. Angiospermas epífitas de uma floresta montana no sul da Bahia, Brasil. Biota Neotropica 14: 1-12.

Liuth, H.S.; Talora, D.C. \& Amorim, A.M. 2013. Phenological synchrony and seasonality of understory Rubiaceae in the Atlantic Forest, Bahia, Brazil. Acta Botanica Brasilica 27: 195-204.

Martini, A.M.; Fiaschi, P.; Amorim, A.M. \& Paixão, J.K. 2007. A hot-point within a hot-spot: a high diversity site in Brazil’s Atlantic Forest. Biodiversity and Conservation 16: 3111-3128.

Perdiz, R.O.; Amorim, A.M. \& Ferrucci, M.S. 2012. Paullinia unifoliolata, a remarkable new species of Sapindaceae from the Atlantic Forest of southern Bahia, Brazil. Brittonia 64: 114-118.

Reitz, R. 1980. Sapindaceae. In: Reitz, R. (org.). Flora ilustrada catarinense. Herbário Barbosa Rodrigues, Itajaí. 160p.

Rizzini, C.T. 1977. Sistematização terminológica da folha. Rodriguésia 29: 103-125.

Rocha, D.S.B. \& Amorim, A.M.A. 2012. Heterogeneidade altitudinal na Floresta Atlântica setentrional: um estudo de caso no sul da Bahia, Brasil. Acta Botanica Brasilica 26: 309-327.

Silva, K.F.; Ferrucci, M.S. \& Groppo, M. 2013. Flora da Serra do Cipó, Minas Gerais: Sapindaceae. Boletim de Botânica da Universidade de São Paulo 31: 99-130.

Somner, G.V. 1997. Sapindaceae. In: Marques, M.L.M.; Vaz, A.S.F. \& Marquete, R. (orgs.). Flórula da APA Cairuçu, Parati, RJ: espécies vasculares. Série Estudos e Contribuições 14: 456-487.

Somner, G.V. \& Ferrucci, M.S. 2004. A new species of Cupania sect. Trigonocarpus (Sapindaceae) from Brazil. Botanical Journal of Linnean Society 146: 217-221.

Somner, G.V. \& Ferrucci, M.S. 2009. Sapindaceae. In: Stehmann, J.R.; Forzza, R.C.; Salino, A.; Sobral, M.; Costa, D.P. \& Kamino, L.H.Y. (eds.). Plantas da Floresta Atlântica. Jardim Botânico do Rio de Janeiro, Rio de Janeiro. Pp. 467-471.

Somner, G.V.; Carvalho, A.L.G. \& Siqueira, C.T. 2009a. Sapindaceae da restinga da Marambaia, Rio de Janeiro, Brasil. Rodriguésia 60: 485-507. 
Somner, G.V.; Ferrucci, M.S.; Rosa, M.M.T. \& Coelho, R.L.G. 2009b. Sapindaceae. In: Martins, S.E.; Wanderley, M.G.L.; Shepherd, G.J.; Giulietti, A.M. \& Melhem, T.S. (eds.). Flora fanerogâmica do estado de São Paulo. Vol. 6. Instituto de Botânica, São Paulo. Pp. 195-255.

Somner, G.V.; Ferrucci, M.S.; Acevedo-Rodríguez, P.; Coelho, R.L.G. \& Perdiz, R.O. 2014. Sapindaceae. In: Lista de espécies da flora do Brasil. Jardim Botânico do Rio de Janeiro. Disponível em $<$ http://floradobrasil.jbrj.gov.br/jabot/floradobrasil/ FB216>. Acesso em 6 janeiro 2014.

Stehmann, J.R.; Forzza, R.C.; Salino, A.; Sobral, M.; Costa, D.P. \& Kamino, L.H.Y. 2009. Diversidade taxonômica na Floresta Atlântica. In: Stehmann, J.R.; Forzza, R.C.; Salino, A.; Sobral, M.; Costa,
D.P. \& Kamino, L.H. (eds.). Plantas da Floresta Atlântica. Jardim Botânico do Rio de Janeiro, Rio de Janeiro. Pp. 3-12.

Tamaio, N. \& Angyalossy, V. 2009. Variação cambial em Serjania caracasana (Sapindaceae): enfoque na adequação terminológica. Rodriguésia 60: 651-666.

Thomas, W.W.; Carvalho, A.M.; Amorim, A.M.; Garrison, J. \& Arbeláez, A.L. 1998. Plant endemism in two forests in southern Bahia, Brazil. Biodiversity and Conservation 7: 311-322.

Valente, A.S.M.; Dias, J.M.; Venda, A.K.L.; Judice, D.M.; Reis Júnior, J.S.; Abreu, M.B. \& Maurenza, D. 2013. Sapindaceae. In: Martinelli, G. \& Moraes, M.A. (orgs.). Livro vermelho da flora do Brasil. Instituto de Pesquisas Jardim Botânico do Rio de Janeiro, Rio de Janeiro. Pp. 952-955.

\section{Lista de Exsicatas}

Acevedo-Rodríguez, P. 1431, 1439, 1456 (5.1); Amorim, A.M. 2519 (4.5), 4383 (1.3), 4973 (1.1), 4974 (2.3), 5009 (4.7), 5137 (2.3), 5148 (2.1), 5241 (1.1), 5736 (4.1), 5761 (4.7), 5945 (4.1), 6077 (2.3), 6093 (4.7), 6368 (4.1), 6369 (1.1), 6563 (4.7), 6960 (4.1), 6973 (2.2), 7222 (4.6), 7223 (4.4), 7583 (1.2), 7629 (2.4), 7713 (1.2), 7714 (3.1), 7741 (3.1), 7743 (3.1), 7875 (1.1); Andreata, R.H.P. 440 (1.1); Belém, R.P. 1174 (4.2); Belém, R.P. 39829 (1.4); Blanchet, J.S. 2353* (2.4); Borges, R.A.X. 506 (5.2), 638 (4.6), 671(3.1); Cardoso, D. 1622 (4.6), 1636 (5.2); Carvalho, A.M.V. 3624 (6.1), 5031 (2.4), 6296 (4.6), 7006 (5.2); Chautems, A. 199 (3.1); Cid Ferreira, C.A. 10932 (6.1); Daneu, L. 28 (4.4), 30 (4.1), 426 (3.2), 427 (1.4), 430 (5.2); Farias, D.S. 332 (2.1); Ferreira, F. 1292 (2.1); Fernandes, D. 779 (4.3); Ferrucci, M.S. 955 (5.1), 965 (4.5); Fiaschi, P. 1681 (6.1), 1819 (3.2), 1913 (1.4), 2647 (2.5), 2806 (1.1), 2869 (2.2); Folli, D.A. 15 (2.4), 1043 (6.1); Franco, G. 2995 (2.1); Glaziou, A.F.M. 8607* (3.2), 11826* (2.1); Goldenberg, R. 1244 (1.4); Guedes, M.L. 3292 (4.4); Hatschbach, G. 18698 (1.2), 45160 (5.1), 48962 (1.2), 51881 (5.1), 65463 (1.3), 68425 (4.5), 75408 (4.5); Ivanauskas, N.M. 55 (3.2); Jardim, A.B. 42 (4.1), 70 (4.1), 112 (1.1); Jardim, J. 297 (6.1), 2148 (6.1), 4376 (1.1), 4865 (1.1), 4861 (4.7), 4705 (2.2), 4787 (1.4), 5290 (1.1), 5409 (2.4); Jost, T. 311 (4.3); Kollmann, L. 6183 (2.1); Krapovickas, A. 23232 (1.2); Lopes, M.M.M. 555 (1.1), 585 (1.1), 746 (2.3), 751 (4.1), 754 (2.2), 777 (4.2), 799(4.1), 800 (4.3), 982 (5.1), 1086 (3.2), 1173 (4.6), 1185 (4.4); Luchiari, C. 62 (2.1); Luschnath s.n. (Martius 483) (6.1); Marquete, R. 1652 (4.3); Mori, S.A. 9303 (6.1), 13046 (6.1); Nelson, B. 1472 (4.2); Neto, M.P. 573 (3.1); Oliveira, C.A.L. 1822 (2.1); Paixão, J.L. 51 (4.2), 772 (1.4), 958 (4.1), 1101 (4.4); Passos, L.A. 342 (2.2); Perdiz, R.O. 52 (4.1), 298 (4.6), 361 (4.1), 397 (4.1), 402 (4.1), 421 (4.4), 432 (2.3), 487 (4.5), 498 (2.3), 519 (4.1), 557 (2.3), 564 (4.5), 642 (4.3), 645 (4.6), 675 (2.1), 699 (4.6), 701 (4.1), 723 (2.4), 725 (6.1), 726 (1.2), 750 (1.3); 939 (6.1); Pinheiro, D.M. 16 (1.4); Reitz, P.R. 3143 (3.2); Rocha, D. 1136 (1.2); Roderjan, C.V. 249 (3.2); Sant'Ana, S.C. 594 (6.1), 817 (4.1), 860 (6.1); Santos, F.S. 288 (4.4); Schwacke 4829 (3.2); Simonelli, M. 1561 (2.1); Souza, V.C. 446 (3.2); Sucre, D. 8798 (1.1); Sylvestre, L. 997 (4.3); Thomas, W.W. 9925 (4.2), 13548 (2.4); Tiepolo, G. 57 (1.3); Vieira, R.F. 1673 (3.1); Walter, B.M.T. 525 (3.1), 2338 A (3.1). 